\title{
Good news for conservation: mitochondrial and microsatellite DNA data detect limited genetic signatures of inter-basin fish transfer in Thymallus thymallus (Salmonidae) from the Upper Drava River
}

\author{
A. Meraner ${ }^{(1), \star}, \mathrm{G}$. Unfer ${ }^{(2)}$, A. Gandolfi ${ }^{(1)}$ \\ Received December 12, 2012 \\ Revised March 20, 2013 \\ Accepted April 2, 2013
}

Key-words:

European

grayling,

Thymallus

thymallus,

genetic

introgression,

Drava/Drau

River,

stocking

\section{ABSTRACT}

In the last few decades, numerous populations of European grayling, Thymallus thymallus, have been suffering from stocking-induced genetic admixture of foreign strains into wild populations. Concordantly, genetic introgression was also reported for grayling stocks inhabiting the Upper Drava River, but all published genetic data based on specimens caught at least a decade ago, when stocking load was strong. Here, we applied mitochondrial control region sequencing and nuclear microsatellite genotyping to Upper Drava grayling fry collections and reference samples to update patterns and extent of human-mediated introgression. In contrast to previous data, we highlighted an almost genetic integrity of Drava grayling, evidencing limited genetic signatures of trans-basin stocking for grayling of Northern Alpine Danubian origin. Recent hybridisation was detected only twice among sixty-nine samples, while several cases of later-generation hybrids were disclosed by linking mitochondrial sequence to nuclear genetic data. The observed past, but very limited recent genetic introgression in grayling from Upper Drava seems to reflect shifting stocking trends, changing from massive introduction of trans-basin fish to more conservation-oriented strategies during the last 27 years. In a conservation context, we encourage pursuing the use of local wild grayling for supportive- and captive-breeding, but underline the need for genetic approaches in brood-stock selection programs. Finally, our integrated results from sibship reconstruction validate our strictly fry-based sampling scheme, thus offering a reasonable alternative also for other rheophilic fish species with similar life-history characteristics.

\section{RÉSUMÉ}

Bonne nouvelle pour la conservation : les données de l'ADN mitochondrial et des microsatellites détectent des signatures génétiques limitées de transfert entre bassins du poisson Thymallus thymallus (Salmonidae) dans le cours supérieur de la rivière Drava

Mots-clés : Au cours des dernières décennies, de nombreuses populations d'ombre commun, Ombre commun, Thymallus thymallus, ont souffert de mélange génétique induit par des alevinages Thymallus thymallus, dans les populations sauvages utilisant des souches étrangères. Une introgression génétique a également été signalée pour des stocks d'ombre de la rivière Drava amont, mais toutes ces données génétiques publiées sont basées sur des

(1) Department of Biodiversity and Molecular Ecology, Research and Innovation Centre, Fondazione Edmund Mach, Via E. Mach 1, 38010 San Michele all'Adige, TN, Italy

(2) Institute of Hydrobiology and Aquatic Ecosystem Management, Max-Emanuelstrasse, Vienna, Austria

* Corresponding author: andreas.meraner@fmach.it 
introgression génétique, rivière Drava, alevinage spécimens capturés il y a au moins une dizaine d'années, lorsque l'alevinage était intensif. Ici, nous avons appliqué un séquençage mitochondrial d'une région de contrôle et un génotypage microsatellite nucléaire sur des lots d'alevins d'ombre de la Drava amont et sur des échantillons de référence pour actualiser les modèles et l'importance de l'introgression due à la gestion. Contrairement aux données précédentes, nous avons mis en évidence une intégrité génétique presque intacte de l'ombre de la Drava, attestant de signatures génétiques limitées des ombres d'alevinage trans-bassin provenant des Alpes du Nord - Danube. Une hybridation récente a été détectée seulement deux fois parmi les soixante-neuf échantillons, tandis que plusieurs cas d'hybrides de générations antérieures ont été révélés en reliant la séquence mitochondriale aux données génétiques nucléaires. Les données antérieures, et l'introgression génétique récente très limitée chez l'ombre de la rivière Drava amont semblent refléter les tendances actuelles d'alevinage, passant de l'introduction massive de poissons trans-bassin à plus de stratégies axées sur la conservation au cours des 27 dernières années. Dans un contexte de conservation, nous encourageons la poursuite de l'utilisation des ombres sauvages locaux pour l'alevinage et l'élevage de stocks en captivité, mais soulignons la nécessité d'approches génétiques dans les programmes de sélection des géniteurs. Enfin, nos résultats intégrés de reconstitution de la fratrie d'origine valident notre plan d'échantillonnage strictement fait d'alevins, offrant ainsi une alternative raisonnable aussi pour d'autres espèces de poissons rhéophiles de caractéristiques biologiques similaires.

\section{INTRODUCTION}

Alpine freshwater fish fauna has entered a crisis phase. In fact, numerous Alpine taxa face a multitude of anthropogenic disturbances, exhibit increasingly restricted distribution areas and are officially ranked in red-list threat categories (Freyhof and Brooks, 2011). This also holds true for European grayling, Thymallus thymallus, L. 1758, a key-species of the middle reaches of Western-Palaeoarctic rivers. The European grayling is of elevated socio-ecological importance in sport fisheries as well as ecosystem integrity (Northcote, 1995). Massive demographic declines of $T$. thymallus have been reported for the entire Alpine mountain range from France to Slovenia (Kirchhofer et al., 1990; Persat, 1996; Uiblein et al., 2001; Gum et al., 2003; Sušnik et al., 2004). In Austria, European grayling was originally widely distributed, constituting the bulk of riverine fish biomass within the 'grayling zone' until the last few decades (Wolfram and Mikschi, 2007). Recently, several river drainages have been affected by severe grayling population collapses (Wiesbauer et al., 1991; Uiblein et al., 2001; Unfer et al., 2004), officially recorded in the 'Austrian Red-list of Freshwater Fishes'. There, the threatened status of T. thymallus was raised in few years from 'Least Concern' (Herzig-Straschil, 1991) to 'Vulnerable' (Spindler et al., 1997; Wolfram and Mikschi, 2007). The causes of local grayling endangerment resemble global freshwater fish threat categories, i.e. water pollution, species invasions, overexploitation, flow modification and habitat degradation (reviewed in: Maitland, 1995; Dudgeon et al., 2006). As for Alpine grayling populations, the impact of species invasions is exemplified by the development of self-sustaining stocks of rainbow trout (Schmutz, 1995) and overexploitation by bird depredation (Uiblein et al., 2001). Finally, the most significant threats for wild grayling populations derive from flow modifications as well as habitat degradation, mainly due to river regulation and hydropower use (e.g. Unfer et al., 2004).

As a consequence, grayling stocking programs were initiated in several Alpine rivers in order to counterbalance the decline of natural populations (e.g. Persat, 1996). However, in most cases stocking programs ignored the genetic architecture of local wild grayling populations and disregarded the existence of multiple highly-divergent genetic lineages within T. thymallus, most likely reflecting distinct glacial refugia (Weiss et al., 2002). Thus, the translocation of spatially separated and genetically divergent grayling acted as an effective path for humanmediated secondary contact of allopatric grayling populations, potentially leading to genetic introgression (e.g. Sušnik et al., 2004). 
A similar scenario of genetic introgression of non-native T. thymallus into wild populations was also proposed for the Upper Drava drainage by Duftner et al. (2005). There, in the absence of stable commercial hatchery stocks, the authors reported regular translocation of grayling into the Drava, consisting of several thousand specimens from the Inn River (Northern Alpine Danubian basin) introduced around 27 years ago. Duftner et al. (2005) provided mitochondrial control region sequence data from Drava and Inn grayling and found an elevated $(38 \%)$ frequency of Northern Alpine Danubian genetic variants in Drava River grayling specimens, interpreted as a clear genetic imprint of restocking.

Likewise, Weiss et al. (2013) re-analysed these fish sampled before 2005 by using 13 microsatellite loci. The latter authors showed that within almost all Southern Alpine Danubian samples, and explicitly also the Upper Drava population, genetic introgression with Northern Alpine stocks was extensive (Weiss et al., 2013). However, these studies might not be representative for the present-day situation, given the rapid shift in fisheries management from former trans-alpine translocation to supportive breeding actions, using wild-born individuals. Here, we applied both mitochondrial and nuclear genetic markers to update patterns and extent of introgression between allochthonous hatchery-derived and native grayling from the Upper Drava using young of the year fish sampled in 2012. In addition, the present work serves as a preliminary genetic survey (feasibility study) aimed to build a reliable basis for ecologically sound conservation programs, including the possible formation of captive breeding strains of $T$. thymallus in conjunction with supporting breeding actions. Since adult grayling can hardly be acclimated to a hatchery environment, the formation of brood-stocks needs to rely on wild-born fry individuals. We therefore evaluated the representativeness of a strict fry-based sampling scheme through the inference of sibship structure of collected individuals.

\section{MATERIAL AND METHODS}

\section{> HYDROMORPHOLOGY, STUDY AREA AND SAMPLING STRATEGY}

The Drava River represents the fourth major tributary of the Danube River with a length of more than $700 \mathrm{~km}$ and a mean total runoff of $670 \mathrm{~m}^{3} \cdot \mathrm{s}^{-1}$. From the river source close to the Toblacher Feld (South Tyrol, Italy), the Drava flows eastwards through Eastern Tyrol and Carinthia (Austria), through Slovenia and Croatia and enters the Danube near Osijek. Within the area of interest, limited to the westernmost stretch of the river in Carinthia, the nivoglacial Drava is characterised by a mean discharge of $70 \mathrm{~m}^{3} \cdot \mathrm{s}^{-1}$ and a strongly straightened channel geometry as a consequence of massive stabilisation measures (Muhar et al., 2008). Comparatively large-scale river rehabilitation measures, resulting from recent restoration programs (Unfer et al., 2004, 2011), disrupt the otherwise massively regulated river bed. Actual fish biocenosis comprises at least 18 species, with European grayling ( $T$. thymallus), brown trout (Salmo trutta) and rainbow trout (Oncorhynchus mykiss), constituting around 93\% of total freshwater fish abundance in the upper Carinthian Drava (Unfer et al., 2011). Grayling biomass of the Upper Drava seems to undergo a severe crisis phase as catch per unit effort (CPUE) electro-fishing data have been declining from around $150 \mathrm{~kg} \cdot \mathrm{ha}^{-1}$ in 1989 (Jungwirth et al., 1990) to only $30 \mathrm{~kg} \cdot \mathrm{ha}^{-1}$ in 2004 (Unfer et al., 2004). The estimated mean grayling biomass can roughly be translated into 4000 to 5000 breeders of the total Upper Drava grayling metapopulation, inhabiting a continuous river stretch of approximately $90 \mathrm{~km}$ (Unfer et al., 2011). At present, a slight recovery of grayling populations seems to occur in rehabilitated stretches of the Upper Drava River (Unfer et al., 2011).

A total of $69 T$. thymallus fry specimens were collected by hand nets from three river banks within the Upper Drava River system in June 2012 (Table I, Figure 1B). All sampling sites were situated within the easternmost part of the Drava River in the Austrian province of Carinthia, close to the Tyrolean-Carinthian borderline. The longitudinal sequence of sampling sites was DRAV_D, DRAV_G and DRAV_R, with hydrographical distances between adjacent sampling sites being approximately $8 \mathrm{~km}$ between DRAV_D and DRAV_G and $5 \mathrm{~km}$ between DRAV_G and DRAV_R (Table I). The uppermost Drava sampling site (DRAV_D) of our study is situated 


\begin{tabular}{|c|c|c|c|c|c|c|c|c|c|c|c|}
\hline \multirow{4}{*}{\multicolumn{2}{|c|}{ 臂 }} & 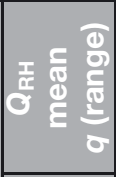 & 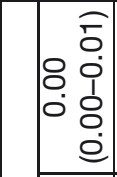 & 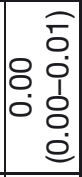 & 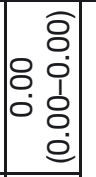 & 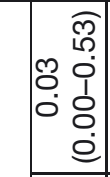 & \begin{tabular}{ll} 
& \multicolumn{1}{c}{} \\
0 & 0 \\
0 & 1 \\
0 & 0 \\
0 & 0 \\
0
\end{tabular} & 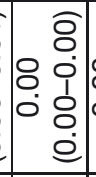 & 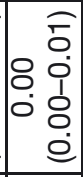 & 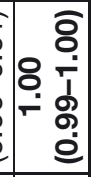 & 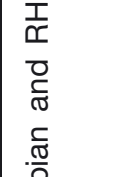 \\
\hline & & 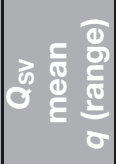 & 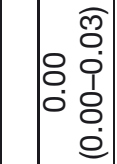 & 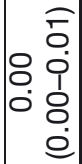 & $\left|\begin{array}{ll} & \widehat{\sigma} \\
0 & 0 \\
0 & 1 \\
0 & 0 \\
0 & 0 \\
0 & 0\end{array}\right|$ & 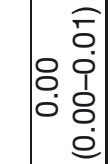 & \begin{tabular}{ll} 
& \multicolumn{1}{c}{} \\
0 & 0 \\
0 & 1 \\
0 & 0 \\
0 & 0 \\
& 0
\end{tabular} & $\mid$\begin{tabular}{c}
0 \\
8 \\
8 \\
\hdashline \\
\hdashline \\
0 \\
0 \\
0
\end{tabular} & 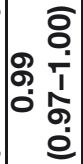 & $\left|\begin{array}{ll} & 0 \\
0 & 0 \\
0 & 0 \\
0 & 0 \\
0 & 0 \\
0 & 0\end{array}\right|$ & 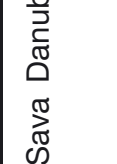 \\
\hline & & 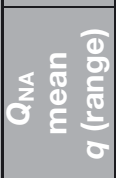 & 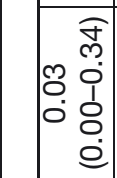 & 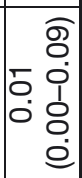 & $\mid \begin{array}{rr} & \widehat{\sigma} \\
0 & 0 \\
0 & 0 \\
0 & 1 \\
0 & 0 \\
0 & 0\end{array}$ & 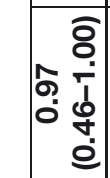 & $\begin{array}{l}3 \\
8 \\
8 \\
8 \\
0 \\
0 \\
\\
0 \\
0\end{array}$ & 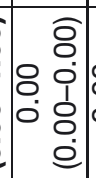 & 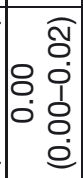 & $\begin{array}{ll} & \widehat{\sigma} \\
0 & 0 \\
0 & 9 \\
0 & 0 \\
0 & 0 \\
0 & 0\end{array}$ & $\begin{array}{l}\ddot{3} \\
\frac{0}{0} \\
\frac{0}{3}\end{array}$ \\
\hline & & 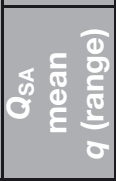 & 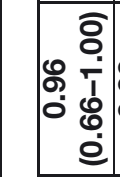 & 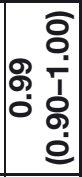 & 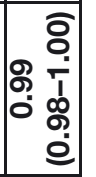 & 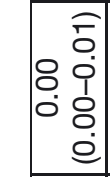 & $\begin{array}{ll} & \overline{0} \\
0 & 0 \\
0 & 0 \\
0 & 0 \\
0 & 0 \\
0\end{array}$ & $\mid \begin{array}{ll} & \\
0 \\
0 & 0 \\
0 & 1 \\
0 & 0 \\
0 & 0 \\
0 & 0\end{array}$ & 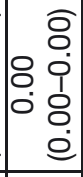 & \begin{tabular}{|ll} 
& 0 \\
0 & 0 \\
0 & 0 \\
0 & 0 \\
0 & 0 \\
& 0 \\
\end{tabular} & 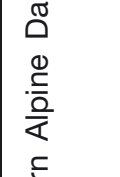 \\
\hline & 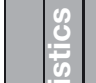 & 오 & 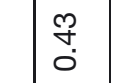 & $\begin{array}{l}\mathscr{Q} \\
\stackrel{0}{0}\end{array}$ & @ి & $\begin{array}{l}\stackrel{g}{+} \\
\text { ○े }\end{array}$ & $\begin{array}{l}0 \\
\text { மீ } \\
0\end{array}$ & $\begin{array}{l}\stackrel{+}{J} \\
\stackrel{0}{0}\end{array}$ & 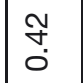 & $\begin{array}{l}\text { ơ } \\
\text { o }\end{array}$ & \\
\hline & $\left|\begin{array}{l|}\frac{1}{9} \\
\frac{5}{2} \\
0 \\
0\end{array}\right|$ & 오 & ז̊ & $\begin{array}{l}\text { J } \\
\text { ¿ }\end{array}$ & $\begin{array}{l}\dot{0} \\
\dot{0} \\
0\end{array}$ & $\begin{array}{l}10 \\
10 \\
0 \\
0\end{array}$ & $\begin{array}{l}\text { Ñ } \\
\text { مْ } \\
0\end{array}$ & 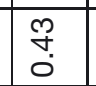 & fo & $\begin{array}{l}0 \\
\stackrel{0}{0} \\
0\end{array}$ & \\
\hline & 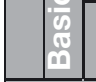 & $\varangle$ & $\begin{array}{l}\hat{0} \\
\dot{0}\end{array}$ & 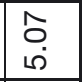 & $\begin{array}{l}\infty \\
\infty \\
10 \\
\end{array}$ & $\frac{m}{6}$ & $\begin{array}{l}\mathscr{R} \\
\stackrel{0}{0} \\
\dot{\sim}\end{array}$ & $\frac{m}{\oplus}$ & $\begin{array}{l}\rho \\
\stackrel{\rho}{n}\end{array}$ & $\begin{array}{l}\text { 守 } \\
\text { ம. }\end{array}$ & \\
\hline & & $z$ & 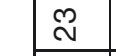 & $\sim$ & $\stackrel{\sim}{\sim}$ & $\stackrel{\sim}{\sim}$ & $\stackrel{\sim}{\sim}$ & $\stackrel{\infty}{\sim}$ & 으 & $\stackrel{\mathscr{N}}{ }$ & \\
\hline & & $\frac{I}{\alpha x}$ & . & . & . & . & . & & . & $\stackrel{\sim}{\sim}$ & \\
\hline & *) & के & - & $\cdot$ & . & . & . & $\stackrel{\sim}{\ulcorner}$ & 0 & . & \\
\hline & $\frac{80}{00}$ & $\$$ & - & . & $\nabla$ & $\stackrel{*}{*}$ & $\stackrel{*}{\star}$ & & . & . & \\
\hline & $z$ & क & $\bar{\sim}$ & N & 尺 & . & . & & . & . & \\
\hline ? & E & $\begin{array}{l}\text { की } \\
\frac{0}{2}\end{array}$ & б. & $\stackrel{8}{\circ}$ & $\begin{array}{c}0 \\
\infty \\
0 \\
0\end{array}$ & : & 8: & ৪ & 8: & 8 & 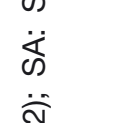 \\
\hline & & $z$ & $\stackrel{\mathscr{N}}{ }$ & N & $\stackrel{\vec{N}}{ }$ & $\bar{N}$ & N & $\stackrel{\wedge}{\circ}$ & 0 & $\stackrel{\mathscr{N}}{ }$ & \\
\hline $\begin{array}{l}\mathbb{D}^{0} \\
\text { है } \\
\text { है }\end{array}$ & $\frac{8}{\frac{9}{10}}$ & $\begin{array}{l}\frac{1}{2} \\
\frac{0}{3} \\
\frac{3}{2} \\
\frac{2}{0} \\
\end{array}$ & $\begin{array}{l}w \\
i n \\
\circ \\
\stackrel{m}{\square}\end{array}$ & $\begin{array}{l}w \\
\square \\
\check{c} \\
\stackrel{m}{\square}\end{array}$ & 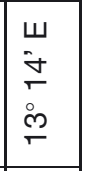 & $\begin{array}{l}w \\
\dot{0} \\
\stackrel{+}{\leftarrow}\end{array}$ & $\begin{array}{l}w \\
\stackrel{+}{\sigma} \\
\stackrel{\leftarrow}{\mp}\end{array}$ & $\begin{array}{l}w \\
\vdots \\
\sim \\
\circ \\
\dot{\square}\end{array}$ & $\begin{array}{l}ш \\
0 \\
\llcorner \\
\circ \\
+\end{array}$ & 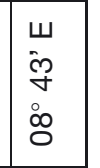 & 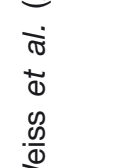 \\
\hline ఏ) & ن & . & \begin{tabular}{l}
$Z$ \\
ì \\
\multirow{\gamma}{*}{} \\
$\vdots$ \\
$\dot{q}$
\end{tabular} & $\begin{array}{l}Z \\
\dot{j} \\
\dot{y} \\
i \\
\dot{y}\end{array}$ & $\begin{array}{l}z \\
i n \\
o \\
i o \\
q\end{array}$ & $\begin{array}{l}z \\
\text { o } \\
0 \\
0 \\
\infty \\
\forall\end{array}$ & $\begin{array}{l}z \\
\text { o } \\
\dot{y} \\
\vdots \\
\dot{y} \\
\end{array}$ & $\begin{array}{l}Z \\
i \\
\forall \\
i \\
i j\end{array}$ & $\begin{array}{l}Z \\
\text { in } \\
+ \\
i n \\
i\end{array}$ & \begin{tabular}{l}
$z$ \\
$i v$ \\
\multirow{y}{*}{} \\
$\stackrel{y}{\checkmark}$
\end{tabular} & 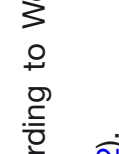 \\
\hline 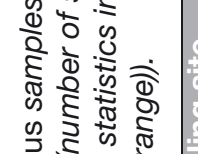 & 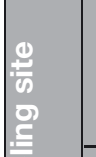 & 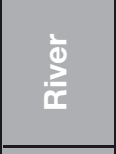 & $\begin{array}{l}\stackrel{\pi}{\pi} \\
\stackrel{\pi}{\Delta}\end{array}$ & $\begin{array}{l}\stackrel{\pi}{\pi} \\
\stackrel{0}{0}\end{array}$ & 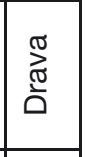 & 巨્ & 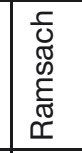 & $\begin{array}{l}\text { 등 } \\
\text { On }\end{array}$ & $\begin{array}{l}\frac{\tilde{\sigma}}{\overline{5}} \\
\frac{\pi}{0} \\
\widetilde{\pi}\end{array}$ & 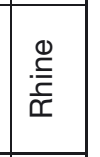 & $\begin{array}{l}\bar{d} \\
\underline{\sigma} \\
\check{\sigma} \\
\text { og }\end{array}$ \\
\hline 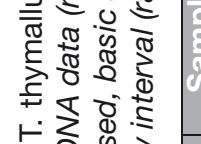 & 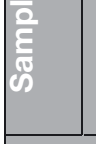 & 유. & 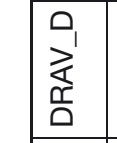 & \begin{tabular}{|l|} 
\\
\\
$\gtrless$ \\
$⿱ 亠 乂$ \\
0
\end{tabular} & 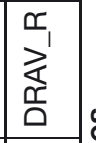 & $\underline{z}$ & 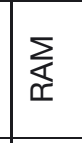 & $\begin{array}{l}\text { 㽟 } \\
\text { Oे }\end{array}$ & 足 & 甚 & ㄷ 요 \\
\hline & i & & - & $\sim$ & $m$ & 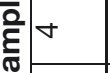 & 10 & 0 & $\wedge$ & $\infty$ & $\frac{\pi}{6} \frac{\pi}{ \pm}$ \\
\hline$\frac{1}{2}$ & 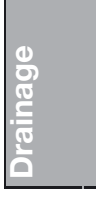 & & 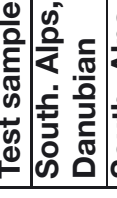 & 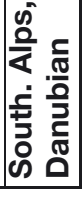 & 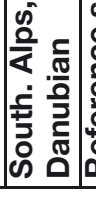 & 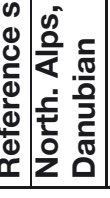 & 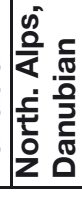 & 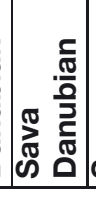 & 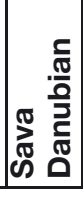 & 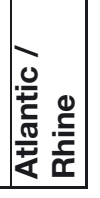 & 范 \\
\hline
\end{tabular}




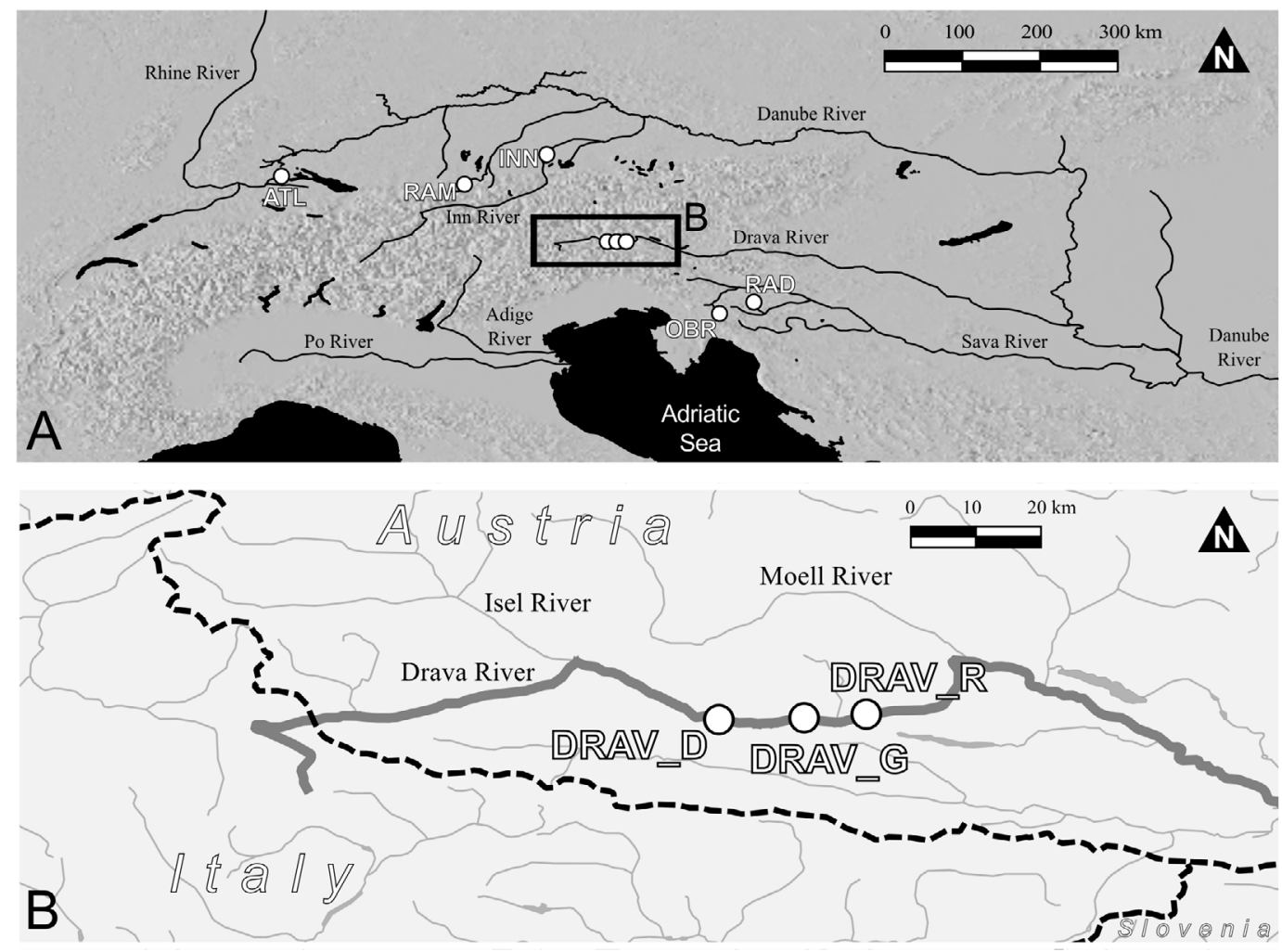

Figure 1

(A) Spatial distribution of test (Drava River) and reference samples (Inn, Ramsach, Obrh, Radulja and Rhine Rivers) and (B) details of sampling sites within the Upper Drava drainage. Detailed information of sampling sites can be found in Table I.

$15 \mathrm{~km}$ downstream from the easternmost sampling site presented in Duftner et al. (2005). All Drava-related samples analysed in Duftner et al. (2005), Weiss et al. (2013) as well as the present study were spatially distributed along a longitudinal river stretch, free of impassable barriers to migration, such as dams or weirs.

In addition to Upper Drava grayling samples, Northern Alpine Danubian (Inn and Ramsach Rivers, $N=48$ ), Sava Danubian (Obrh and Radulja Rivers, $N=28$ ) and Atlantic (Rhine River, $N=23$ ) samples were kindly provided by colleagues (refer to Acknowledgements) and were included in the present study as reference samples to track the origin of introgressed individuals in the Upper Drava system (Table I, Figure 1A). The choice to include wild grayling as reference samples was motivated by the following rationale; in Austria, almost all stocked grayling directly derive from wild populations, given the difficulty of rearing grayling in captivity (Unfer, unpublished data). Therefore, in contrast to brown trout, for which a long tradition of strictly hatchery-propagated stocks are available, the usage of wild populations with different phylogeographic genetic set-up seems a valuable option to study introgression in grayling.

\section{>MOLECULAR TECHNIQUES AND DATA ANALYSIS}

Total nucleic acid was extracted from grayling tissue samples preserved in absolute ethanol by using a standard salting-out protocol (Bruford et al., 1998). Molecular screening of grayling specimens, including both mitochondrial control region (CR) sequencing as well as microsatellite (SSR) genotyping, was achieved as follows.

First, the Drava sample-set $(N=69$, Table I) was subjected to CR sequencing by adopting the methodology described in detail in Meraner and Gandolfi (2012). This was done to unravel the presence and distribution of native (Southern Alpine Danubian, sensu Weiss et al., 
2002) and putatively introduced CR genetic variants within the area of interest. In addition to Drava samples, CR sequence data from reference samples were newly generated for Sava Danubian $(\mathrm{OBR}=17 ; \mathrm{RAD}=6)$ and Atlantic $(\mathrm{ATL}=23)$ samples, while haplotype information from Northern Alpine Danubian populations (INN = 21; RAM =22) were obtained from a published dataset (Meraner and Gandolfi, 2012). From the total available dataset $(N=168)$, DNA extracts from ten specimens did not yield analysable sequence data, thus reducing the mtDNA dataset to 158 individual sequences. CR genetic variants were aligned to haplotypes presented in Meraner and Gandolfi (2012) and available from GenBank. All sequences were checked by eye and assigned to already published haplotypes or deposited in GenBank in the case of the yet un-described genetic variants. Phylogenetic relationships were analysed by haplotype networks using TCS software (Clement et al., 2000).

Second, the complete dataset $(N=168)$, consisting of the three Drava samples as well as Northern Alpine Danubian, Sava Danubian and Atlantic reference samples was genotyped at 15 SSR markers (Table I). Six tetranucleotide, i.e. TAR100, TAR103, TAR104, TAR108 and TAR110 (Diggs and Ardren, 2008) as well as BFR0013 (Koskinen and Primmer, 2001) and nine dinucleotide markers, i.e. BFRO004 (Snoj et al., 1999), BFRO005, BFRO007, BFRO009 (Sušnik et al., 1999a), BFRO010, BFRO011 (Sušnik et al., 2000), BFR0015 (Sušnik et al., 1999b), OGO2 (Olsen et al., 1998) and ONE2 (Scribner et al., 1996), were assayed. Polymerase chain reaction (PCR) annealing temperature was $55^{\circ} \mathrm{C}$ for all BFRO loci plus TAR103, while for all other TAR loci plus microsatellite markers OGO2 and ONE2 an annealing temperature of $58{ }^{\circ} \mathrm{C}$ was applied. PCRs were performed in total volumes of $10 \mu \mathrm{L}$ containing $0.2 \mu \mathrm{M}$ of both forward (labelled with the fluorescent dyes FAM; Invitrogen, Groningen, Netherlands; NED, PET or VIC; Applied Biosystems, Foster City, CA, USA) and reverse primers, $0.1 \mathrm{mM}$ dNTP mix (Invitrogen), $0.75 \mathrm{U}$ of Amplitaq Gold (Applied Biosystems), $1 \times$ AmpliTaq Gold Buffer, $2.5 \mathrm{mM} \mathrm{Mg}^{2+}$ and approximately $50 \mathrm{ng}$ of DNA template. Samples were run on an ABI Prism 3700 Genetic Analyzer (Applied Biosystems) and fragments were sized and assigned to particular size classes by using the GeneMapper ${ }^{\circledR}$ software version 4.0 (Applied Biosystems).

Number of alleles $(A)$, observed $\left(H_{\circ}\right)$ and expected $\left(H_{e}\right)$ heterozygosities, departures from Hardy-Weinberg (HW) expectations (Fisher's exact test; Guo and Thompson, 1992), linkage equilibrium (Chi-square test; Slatkin and Excoffier, 1996) and pairwise $F_{S T}$ values were calculated in ARLEQUIN v3.5.1.2 (Excoffier and Lischer, 2010). The presence of null alleles was tested by using MICRO-CHECKER v2.2.3 (Van Oosterhout et al., 2004).

Significance of all multiple statistical tests was corrected by using the false discovery rate method (FDR) implemented in the software QVALUE (Storey, 2002).

Overall genetic relationships between European grayling samples belonging to the three Upper Drava as well as five reference samples were depicted by factorial correspondence analysis (FCA) as implemented in GENETIX v4.0 software (Belkhir et al., 1999).

Population structure and hybridisation between different grayling (meta)populations were examined using STRUCTURE 2.3.2.1 (Pritchard et al., 2000). STRUCTURE bases on a Bayesian clustering algorithm facilitating the partition of individuals into groups with basic clustering criteria being the minimisation of gametic phase and Hardy-Weinberg disequilibria. The most likely number of genetic clusters $(K)$ represented by our grayling dataset was estimated using two alternative approaches (constant model parameters: tested from $K=1$ to $K=10$ genetic clusters, each with ten replicates consisting of 100000 burn-in and 1000000 markov chains; admixture model with independent allele frequencies). First, we used the methodology presented in Pritchard et al. (2000) and the ad hoc statistic 'estimated Ln Prob. of Data', since the value of $\mathrm{K}$ that maximises the estimated model In-likelihood, $\ln (P(X \mid K))$, is often a sensible choice for the number of clusters presented by the dataset (Falush et al., 2003). Second, the most likely number of $K$ was estimated by following the approach presented in Evanno et al. (2005). Thus, we computed the model $\Delta K$ parameter based on the rate of change in the In probability of data between successive $K$ values. For the most likely value of $K$, individual admixture proportions ( $q$-values; i.e. the estimated membership coefficients for each individual in each cluster) and population-level admixture estimates (Q-values; i.e. the mean of 
individual q-values for a given sample) were calculated as the mean value among replicates, after checking for convergence of the independent replicate chains.

Our genetic survey was exclusively based on early young of the year Drava grayling. We used COLONY v2.0 software package (Wang, 2004, 2012; Jones and Wang, 2010) to depict the most likely sibship structure of the Drava grayling dataset. Unlike most available pedigree reconstruction softwares, COLONY implements full-pedigree likelihood methods to infer sibship among individuals using multilocus genotypic data. Even in the absence of candidate parental samples, COLONY clusters offspring specimens into either full-sib (FS, sharing both parents), half-sib (HS, sharing father or mother) or unrelated individuals. For our analysis, we assumed a polygamous mating scheme for both sexes, generally reported in ecological studies concerning T. thymallus (Fabricius and Gustafson, 1955; Northcote, 1995). We executed five independent COLONY simulations under the full likelihood method, which has been shown to be the most accurate sibship reconstruction algorithm (Wang, 2004, 2012; Wang and Santure, 2009). Finally, we used a sibship complexity prior, which reduces the possibility of erroneously misclassifying unrelated or loosely related specimens as half-siblings. The use of the sibship complexity prior is advisable in the context of weak family structure, polygamy and limited genotypic resolution power (J. Wang, personal communication), and seems thus to apply to our dataset. Finally, we assumed an overall genotyping error rate of 0.02 (allelic drop-out and other error types) and included mtDNA haplotype information to infer excluded maternal sibship. Thereby, maternal sibship was excluded for sample pairs with incompatible $\mathrm{CR}$ haplotypes. We estimated the number and mean size of HS and nested FS families, their spatial distribution as well as the expected number of parents likely to have given rise to the observed grayling fry collection.

\section{RESULTS}

\section{> MITOCHONDRIAL CONTROL REGION (CR) SEQUENCE DATA}

CR sequences of 158 grayling specimens ( $N=69$ test samples from Drava River plus 89 reference samples) clustered into four major mitochondrial lineages: Southern Alpine Danubian (SA), Northern Alpine Danubian (NA), Sava Danubian (SV) and Mixed Central European (RH) clades (sensu Weiss et al., 2002; Table I; Figure 3B; Online Resource 1).

Test samples of the Drava River were predominantly associated with SA haplotypes, reaching frequencies of $0.91,1.00$ and 0.83 within sampling sites DRAV_D, DRAV_G and DRAV_R, respectively. In addition, low frequencies of the NA and one occurrence of the SV haplogroups were detected (Table I). For the SA clade, five previously described CR genetic variants, Da5, Da6, Da7, Da8, and Da13 (Weiss et al., 2002) were identified, while a sixth, new, SA haplotype (Da36) was associated with a fish from DRAV_G (GenBank accession: JX524179). NA clade haplotypes detected in Drava samples were Da4 and Da11 (Weiss et al., 2002), while the SV clade was represented by haplotype Da23 (Weiss et al., 2002).

As expected, CR haplotypes of reference samples from the Sava populations OBR and RAD entirely clustered into the SV clade (Da22, Da23, Weiss et al., 2002; Da34, Meraner and Gandolfi, 2012), while the Rhine River reference sample was fixed for $\mathrm{RH}$ genetic variants (At14, Weiss et al., 2002; AT26, GenBank acc. n. AY841359, in Gum et al., 2005; At27, Meraner and Gandolfi, 2012; At29, new haplotype, Genbank accession: JX961600) (see Online Resource 1). The At29 haplotype sequence was characterised by the occurrence of a four-fold $82 \mathrm{bp}$ repeat in the right domain of the control region, as previously described for different $\mathrm{RH}$ haplotypes from the same drainage (Weiss et al., 2002; Gum et al., 2005). Such a feature has been reported as being common among different salmonids (Sell and Spirkovski, 2004). Each additional repeat unit in the control region was therefore removed from the alignment, since considered phylogenetically uninformative.

CR sequence data of the INN and RAM samples were obtained from Meraner and Gandolfi (2012). Both samples were fixed for NA genetic variants Da1, Da4, Da11 (Weiss et al., 2002) and Da30, Da33 and Da35 (Meraner and Gandolfi, 2012) (Online Resource 1). 
Table II

Genetic differentiation $\left(F_{\mathrm{ST}}\right)$ between sample pairs. Numbers in bold were highly significant $(P<0.01)$, while normal font values were not significant $(P>0.05)$. Sample codes according to Table $I$.

\begin{tabular}{|l|c|c|c|c|c|c|c|c|}
\cline { 2 - 10 } \multicolumn{1}{c|}{} & DRAV_D & DRAV_G & DRAV_R & INN & RAM & OBR & RAD & ATL \\
\hline DRAV_D &. & & & & & & & \\
\hline DRAV_G & 0.01 &. & & & & & & \\
\hline DRAV_R & 0.01 & -0.01 &. & & & & & \\
\hline INN & 0.35 & 0.38 & 0.40 &. & & & & \\
\hline RAM & $\mathbf{0 . 3 9}$ & $\mathbf{0 . 4 2}$ & $\mathbf{0 . 4 4}$ & 0.05 &. & & & \\
\hline OBR & $\mathbf{0 . 4 7}$ & $\mathbf{0 . 4 9}$ & $\mathbf{0 . 5 0}$ & $\mathbf{0 . 4 1}$ & $\mathbf{0 . 4 3}$ &. & & \\
\hline RAD & $\mathbf{0 . 4 7}$ & $\mathbf{0 . 4 9}$ & $\mathbf{0 . 5 1}$ & $\mathbf{0 . 4 0}$ & $\mathbf{0 . 4 2}$ & $\mathbf{0 . 0 5}$ &. & \\
\hline ATL & $\mathbf{0 . 5 2}$ & $\mathbf{0 . 5 3}$ & $\mathbf{0 . 5 5}$ & $\mathbf{0 . 4 3}$ & $\mathbf{0 . 4 5}$ & $\mathbf{0 . 5 1}$ & $\mathbf{0 . 4 8}$ &. \\
\hline
\end{tabular}

\section{$>$ MICROSATELLITE DATA}

\section{Basic statistics}

The total sample-set ( $N=168$; 69 Drava samples plus 99 reference samples) was subjected to microsatellite analysis (Table I). Mean number of alleles $(A)$ ranged from 1.13 for locus BFRO009 to 11.13 for locus TAR110. All loci were polymorphic when considering the complete dataset, while a total of 11 instances of a sample-specific monomorphic locus (BFRO009, TAR110 and OGO2) were detected. In detail, locus BFRO009 showed a monomorphic allelic pattern in seven of eight samples, fixed for the allele of size 247 in all samples of Danubian origin. Population-level mean number of alleles ranged from 3.13 at sample OBR to 6.13 at RAM (Table I). Expected heterozygosity $\left(\mathrm{H}_{\mathrm{e}}\right)$ varied between 0.43 at sampling site OBR and 0.55 at site INN (Table I). Departure from Hardy-Weinberg (HW) equilibrium was tested for every locus within samples (109 tests) and revealed six significant departures from HW expectations after false discovery rate correction (FDR). Deviations from HW were distributed among four loci (i.e. BFR0010, TAR110, TAR104 with one deviation each; TAR100 with three deviations). Since at locus TAR100 all three HW deviations were due to observed heterozygosity deficits and MICRO-CHECKER results indicated the possibility of null-alleles, we tested the potential bias of putative null alleles and/or occurrences of short allele dominance at this locus. Specifically, we re-performed FCA and assignment tests by excluding locus TAR100 from the original dataset. Both datasets (based on either 15 or 14 loci) generated fully compatible results and the original dataset of 15 microsatellite loci was thus retained. Occurrences of linkage disequilibrium were tested between all pairs of loci and within all samples and revealed significant outcomes in five of 840 cases, with no pair of loci evidencing more than one significant result and, thus, not providing statistical support for genetic linkage of loci across samples.

\section{Genetic differentiation, population structure and individual assignment tests}

Genetic differentiation $\left(F_{\mathrm{ST}}\right)$ ranged from -0.01 between sample pairs DRAV_G and DRAV_R to 0.55 between DRAV_R and ATL, respectively (Table II). $F_{S T}$-values were significantly different from zero in 25 of 28 cases, while all comparisons between Drava samples were not significant (Table II). Overall genetic differentiation of the sample-set was represented by FCA (Figure 2). In detail, all specimens from Drava sampling sites (DRAV_D, DRAV_G, DRAV_R) formed a compact cluster, aggregating at the negative end of axis 1, which explained $8.40 \%$ of total inertia. All individuals from ATL clustered along the positive end of axis 1. Finally, Sava Danubian (OBR and RAD) as well as Northern Alpine Danubian (INN and RAM) samples clustered at an intermediate position along axis 1, except for two specimens from the INN sample ( $a$ and $b$ in Figures 2 and $3 \mathrm{~B}$ ), which were positioned at an intermediate position between the INN plus RAM and the ATL cluster. Along axis 2, which explained $7.25 \%$ of total inertia, DRAV, INN, RAM and ATL samples were aggregated close to the negative end of axis 2 (Figure 2). Sava Danubian (OBR and RAD) individuals grouped along the positive axis end, except one fish from RAD, which showed an intermediate value along axis 2 (c in Figures 2 and 3B). 


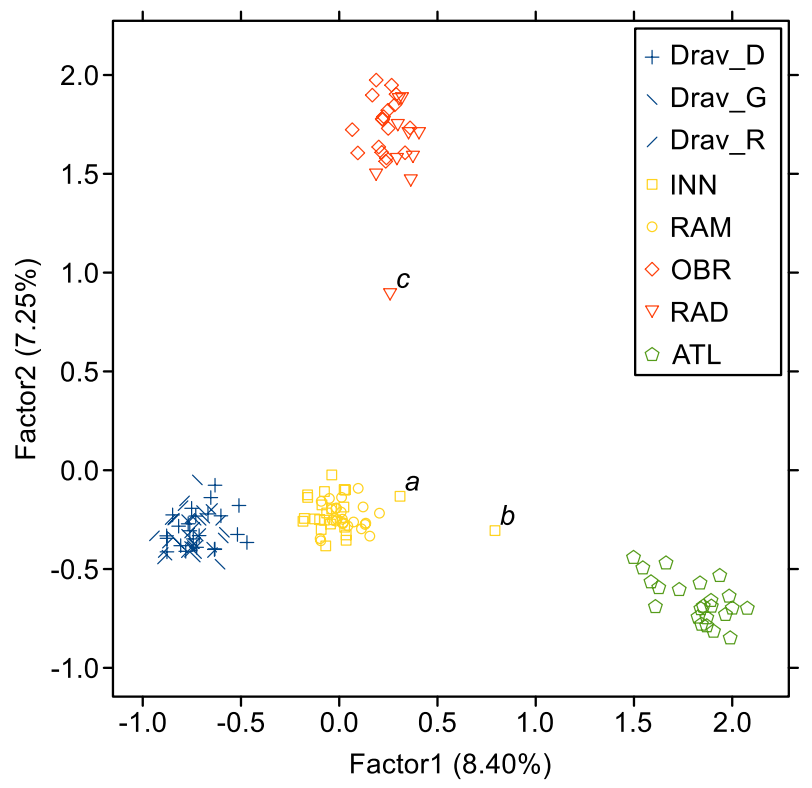

\section{Figure 2}

Projection diagram of the factorial correspondence analysis (FCA) in a bivariate space of test and reference samples of T. thymallus. The first axis accounts for $8.40 \%$, while the second axis accounts for $7.25 \%$ of total inertia. Sampling sites coded according to Table l. Letters $a, b$ and c are used to cross-link samples between Figures 2 and $3 B$.

Individual assignment of test- and reference samples were performed by using STRUCTURE software. Both statistical approaches, $\ln (P(X \mid K))$ (Pritchard et al., 2000) and $\Delta K$ (Evanno et al., $2005)$, aimed at inferring the most probable number of $K$ genetic clusters, clearly indicated $K=4$ as the most likely scenario (Figure $3 A$ ). All independent replicate runs for $K=4$ gave concordant patterns of genetic structure (Figure $3 B$ ), described as follows.

Cluster SA grouped grayling from all three test samples of Drava origin with mean population level $\left(Q_{S A}\right)$ admixture values reaching $0.96,0.99$ and 0.99 at samples DRAV_D, DRAV_G and DRAV_R, respectively (Table I). Individual admixture proportions $\left(q_{\mathrm{SA}}\right)$ at cluster SA ranged from 0.66 to 1.00 , with the lowest $q_{S A}$ values $(0.66$ and 0.75$)$ found for two specimens from DRAV_D, which showed signs of introgression with cluster NA. The latter cluster, NA, comprised all fish from the reference samples INN and RAM with a mean population level $\left(Q_{N A}\right)$ admixture values of 0.97 and 0.99 for samples INN and RAM, respectively. At this cluster, individual admixture values $\left(q_{\mathrm{NA}}\right)$ ranged from 0.46 to 1.00 , with lowest $q_{\mathrm{NA}}$ values $(0.46$ and 0.92$)$ and hence signs of introgression were found for two grayling specimens from INN. These fish were associated with unexpected high $q_{\mathrm{RH}}$ values of Atlantic origin. Finally, both reference samples OBR and RAD aggregated into the SV cluster with mean $Q_{S V}$ values of 0.97 and 0.99 , while the Atlantic reference sample ATL formed the $R H$ cluster $\left(Q_{R H}=1.00\right)$. Clusters $\mathrm{SV}$ and $\mathrm{RH}$ were highly uniform, completely lacking any sign of introgression from foreign clusters.

\section{Sibship reconstruction}

Sibship reconstruction was performed by using COLONY v2.0 software package (Jones and Wang, 2010) and including all Drava samples. We estimated the number and sizes of halfsib (HS) and nested full-sib (FS) families as well as their spatial distribution, assuming a polygamous mating scheme. In addition, we inferred the number of parents likely to have given rise to the observed fry collection.

All five independent runs gave highly convergent results (see Table IIIA for In-likelihood scores of independent replicate runs). Twenty-two out of a total of 69 individuals were identified 


\section{A}

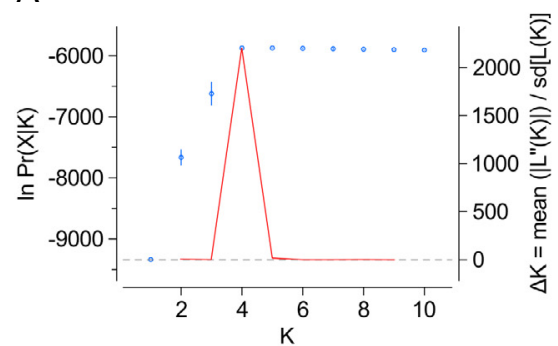

B

q

$\begin{array}{llllll}0.0 & 0.2 & 0.4 & 0.6 & 0.8 & 1.0\end{array}$

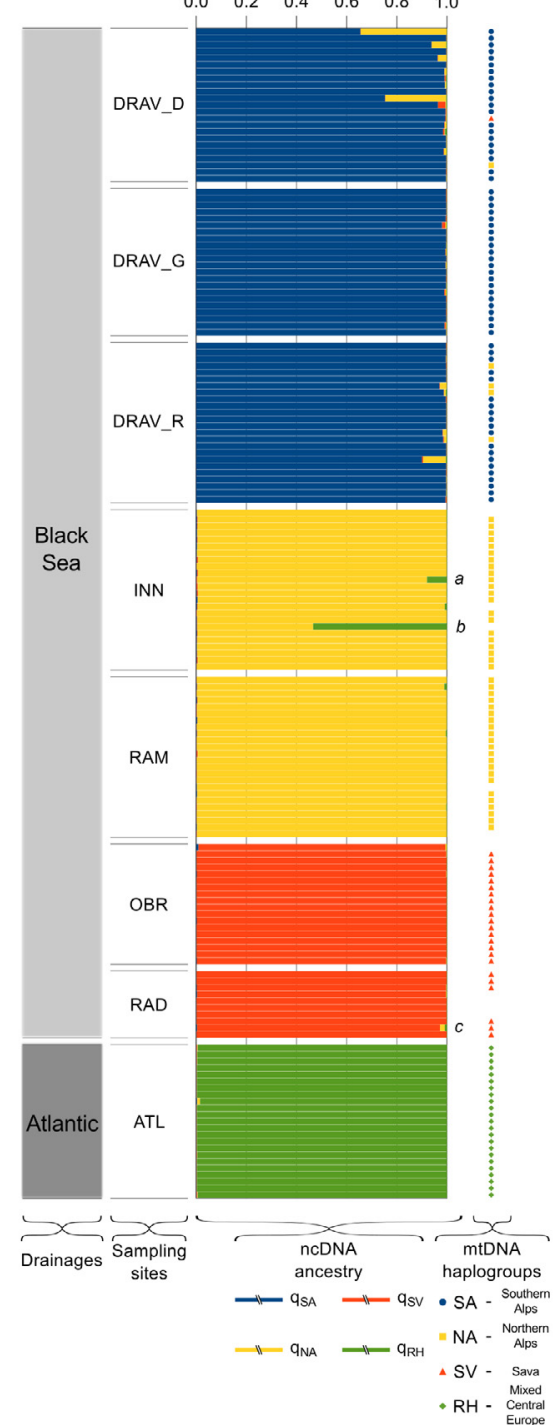

Figure 3

Individual assignment of test (Drava) and reference (Inn, Ramsach, Obr, Radulja and Rhine Rivers) samples of T. thymallus: (A) relationship between the number of genetic clusters $(K)$ and In prob. of data (left second axis) as well as the model $\Delta K$ parameter (right second axis); (B) population structure of test and reference samples. Each vertical bar presents an individual and its proportional membership to one of four genetic groups, i.e. 'Southern Alpine Danubian' (blue), 'Northern Alpine Danubian' (yellow), 'Sava Danubian' (red) and 'Atlantic' (green). MtDNA control region sequence information is coded by blue circles (SA clade), yellow squares (NA), red triangles (SV) and green diamonds (RH). Sample codes according to Table I. Letters $a, b$ and $c$ are used to cross-link samples between Figures 2 and $3 B$. 


\section{Table III}

Summary information on sibship reconstruction of Drava grayling fry collections based on COLONY version 2.0.

In-likelihood values for replicate runs of COLONY under a polygamous mating scheme.

A

\begin{tabular}{|l|c|c|}
\hline run & no. iterations & In-likelihood \\
\hline $\mathbf{1}$ & 66990393 & -1722.15 \\
\hline $\mathbf{2}$ & 68248364 & -1722.24 \\
\hline $\mathbf{3}$ & 72885506 & -1722.30 \\
\hline $\mathbf{4}$ & 71983440 & -1722.24 \\
\hline $\mathbf{5}$ & 70170038 & -1722.24 \\
\hline
\end{tabular}

Numbers and sizes of half-sib (HS) and full-sib (FS) families as well as their spatial distribution. Only families harbouring $>$ one specimen and with probability values $>0.95$ are shown.

$B$

\begin{tabular}{|c|c|c|c|c|c|c|c|c|c|}
\hline \multirow[b]{2}{*}{ family class } & \multirow[b]{2}{*}{$\mathbf{N}$} & \multirow{2}{*}{ mean size } & \multicolumn{7}{|c|}{ spatial distributions } \\
\hline & & & $\mathrm{D}+\mathrm{D}$ & $\mathrm{D}+\mathrm{G}$ & $D+R$ & $\mathrm{D}+\mathrm{G}+\mathrm{R}$ & $G+G$ & $G+R$ & $R+R$ \\
\hline HS $_{\text {paternal }}{ }^{*}$ & 8 & 2.63 & 2 & . & 1 & 3 & 1 & 1 & . \\
\hline $\mathbf{H S}_{\text {maternal }}{ }^{* *}$ & 5 & 2.20 & 1 & . & . & 1 & 1 & 2 & . \\
\hline $\mathbf{F S}^{\star \star * *}$ & 4 & 2.25 & 1 & . & . & 1 & . & 2 & . \\
\hline
\end{tabular}

* half-sib families of individuals sharing identical father.

** half-sib families of individuals sharing identical mother.

*** full-sib families.

$\$$ sample codes according to Table I; all samples are of Drava origin, where e.g. $D+D=D R A V \_D+$ DRAV_D.

as related, when retaining families with $\geqslant 2$ specimens and sibship probabilities $\geqslant 0.95$ only. Related individuals were aggregated into four FS families, nested into a total of 8 paternal and 5 maternal HS family groups (Table IIIB). Spatial distribution of FS and HS families was not limited to single sampling sites. In fact, families clustering individuals from two different (i.e. DRAV_D plus DRAV_R and DRAV_G plus DRAV_R) and all three (i.e. DRAV_D plus DRAV_G plus DRAV_R) sampling localities were identified (Table IIIB).

Finally, a large number of 86 parental individuals, 33 males and 53 females, was estimated by COLONY as the total parenthood likely to have given rise to the observed offspring collection. Effective population size $\left(N_{\mathrm{e}}\right)$ was estimated to be $134(95<95 \%$ confidence interval $<194)$ by using COLONY and the full likelihood method, assuming random mating.

\section{DISCUSSION}

\section{> GENETIC INTEGRITY OF T. THYMALLUS AND STOCKING IMPACT IN THE UPPER DRAVA RIVER}

During the last decade, Upper Drava grayling samples have been analysed within the framework of several genetic studies (mitochondrial sequence data: Uiblein et al., 2001; Weiss et al., 2002; Duftner et al., 2005; additional microsatellite data: Weiss et al., 2013). Foremostly, Uiblein et al. (2001) found up to $58 \%$ of putatively stocking-introduced Northern Alpine Danubian (NA) haplotypes in the Upper Drava. Weiss et al. (2002) found concordant massive NA haplotype frequencies and suggested that human-mediated stock transfer might cause genetic introgression. Lastly, Duftner et al. (2005) specifically investigated the impact of stocking on the genetic integrity of Drava $T$. thymallus populations. These authors concluded that the Upper Drava system had been seriously affected by stocking of highly divergent conspecifics, mostly of Northern Danubian origin. In addition, Duftner et al. (2005) hypothesised that the long-term presence of foreign CR haplotypes might indicate genetic introgression, pointing to anthropogenic alteration of the original genetic architecture of Drava grayling. Recently, nuclear genetic data was provided for Austrian grayling populations, but data presented for Drava populations were exclusively based on samples originally used in Duftner et al. (2005) 
(Weiss et al., 2013). The latter authors pointed to extensive anthropogenic introgression within Southern Danubian populations, with almost all of them, also the sample from the Upper Drava River, no longer representing a reference state (Weiss et al., 2013).

Our mitochondrial and nuclear marker based genetic survey of fry collections was designed to provide an update upon genetic patterns and extent of introgression of grayling from the Upper Drava River. According to the cited studies, putatively introduced NA and SV haplotypes were identified among Drava fry specimens. However, in our sample-set these haplotypes were present at much lower frequencies than previously described. We found NA genetic variants at an overall frequency of $7.2 \%$ (five cases), while the presence of SV haplotypes was limited to a single specimen (1.4\%). The limited extent of non-native genetic signatures was furthermore confirmed by microsatellite analyses and was in contrast to major results of Weiss et al. (2013), where extensive introgression was detected in grayling sampled before 2005. In our study, both factorial correspondence as well as individual assignment analyses corroborated the almost complete genetic integrity of Drava fry collections. In detail, mean population-level admixture proportions ranged from 0.96 to 0.99 at DRAV_D, DRAV_G and DRAV_R, providing strong evidence for a Southern Danubian genetic membership of these sample-sets. Pairwise tests of population differentiation supported the distinctness of this Southern Danubian cluster, since Drava samples showed highly significant $F_{\mathrm{ST}}$ values towards Northern Danubian, Sava and Atlantic samples. Within Drava pairwise comparisons, on the other hand, genetic differentiation was not significant, confirming uniformity of the Southern Danubian cluster (Table II).

Clear signs of trans-basin introgression within Drava samples were rare, but detectable at the nuclear genetic level for at least two fish from DRAV_D, which showed low qSA values (0.66 and 0.75 ; $95 \%$ probability intervals $0.46-0.83$ and $0.57-0.91$; Figure $3 \mathrm{~B}$ ) and elevated $q_{\mathrm{NA}}$ values, indicating introgression with fish of NA origin ( $q_{\mathrm{NA}}$ values 0.34 and $0.24 ; 95 \%$ probability intervals $0.16-0.54$ and $0.09-0.43$; Figure $3 \mathrm{~B}$ ).

Notably, we evidenced six cases of NA or SV haplotypic variants associated to a Southern Danubian nuclear genetic pattern (refer to Figure 3B for details). At first glance, such cases of discordant patterns of mitochondrial and nuclear genetic signatures might seem contradictory, but can be explained by the limited resolution power of individual assignment tests. In fact, Vähä and Primmer (2006) investigated efficiency and accuracy of model-based Bayesian assignment methods (e.g. STRUCTURE) and concluded that in complex scenarios of introgression with several hybrid classes, assignment tests tend to underestimate the proportion of individuals with hybrid ancestry. Specifically, Vähä and Primmer (2006) exemplified that even when depending on a relatively high number of 12 nuclear markers in a context of deep genetic divergence of parental groups, $F_{\mathrm{ST}}=0.21$, the backcross identification success should only slightly exceed $60 \%$, mostly due to the misclassification of backcrosses as purebreds. In our study, both number of loci (15) and especially trans-basin genetic differentiation ( $F_{\mathrm{ST}} \sim 0.40$ between Southern and Northern Danubian populations) were considerably higher, thus probably increasing the efficiency of backcross and purebred discrimination. A backcross detection success of above $80 \%$ seems reasonable when referring to Figure 6 in Vähä and Primmer (2006). However, assignment test classification efficiency will not be error-free in our study, as found by the additional use of mitochondrial haplotype information. Thus, we finally propose for our Drava grayling collections a scenario of marginal recent trans-basin hybridisation, while a heavier human-mediated secondary contact, suggested by later-generation hybrids, is likely to have occurred in the past, leaving a molecular trace at the mitochondrial sequence level. This proposed scenario is also in line with the results presented in Weiss et al. (2013), where extensive allochthonous genetic profiles were found among grayling, sampled from the Upper Drava almost a decade ago.

Our scenario is plausible when also considering available stocking data. Duftner et al. (2005) reported massive stocking of grayling of Northern Danubian (Inn River) origin around the year 1985. In addition, the same authors remarked that later on this stocking trend was replaced by more conservation-oriented management strategies, including fish of Drava origin as brood-stock. Similarly, our own review of local stocking protocols highlighted extensive 
trans-basin grayling input of Northern as well as Sava Danubian origin until 1995, while mainly locally bred fish have been stocked from 1998 to 2012 (data not shown). Thus, it seems likely that the observed decreasing genetic signatures of trans-basin stocking in the Upper Drava - from 60\% (Uiblein et al., 2001; Weiss et al., 2002) to 40\% (Duftner et al., 2005) and, finally, to 7\% (this study) - reflect snap-shots of shifting stocking strategies over the last 27 years. In addition, such a rapid 'response' of the genetic set-up of wild grayling populations to changing fisheries management measures suggests a strong dependency of hatchery-derived population portions on yearly stocking inputs and, thus, points once again to poor performance and low reproductive success of salmonid hatchery strains in the wild (Fleming and Petersson, 2001; Fraser, 2008).

\section{>A FRY-BASED SAMPLING STRATEGY - A VIABLE OPTION OR MATTER OF STATISTICAL BIAS?}

In our genetic survey, genetic analyses concerning the Upper Drava grayling were based on fry specimens. The main question to be solved regards the possibility of unintentional 'family sampling' to have biased our research outcomes. Hansen et al. (1997) investigated this problem for brown trout and reported significant genetic bias by confounding family cohorts as distinct populations. The authors ascribed this problem to patchy spatial distribution of territorial young of the year brown trout in the vicinity of their natal redd (Elliott, 1994), therefore increasing the probability of sampling single large family cohorts. Differences in life history would argue against such a sampling problem in T. thymallus. Grayling fry specimens tend to move downstream soon after emergence and aggregate in small groups in suitable fry habitats (Bardonnet et al., 1991). Thus, in conjunction with an often reported pronounced polygamous mating behaviour (Fabricius and Gustafson, 1955; Northcote, 1995), sampling of fry cohorts should be representative for at least a large portion of the grayling spawning community in the area of interest.

Sibship reconstruction performed by COLONY statistically supported the above mentioned predictions from life-history observations of $T$. thymallus. Only 22 out of 69 specimens were related and a large number of 86 parental individuals most probably gave rise to the investigated fry collections. Family structure within Drava fry collections was weak, highlighting a low number of family groups. In addition, standard genetic diversity indices within Drava samples were high and thoroughly comparable to our reference samples from Northern as well as Sava Danubian and Atlantic origin, that were not being based on fry collections (Table I). Moreover, COLONY calculations estimated a high effective population size $\left(N_{e}=134\right)$, which could be translated into a theoretical number of breeders in the grayling metapopulation. By taking into account the $N_{e} / N_{b}$ ratio of 0.14 proposed by Palstra and Ruzzante (2008), our $N_{e}$ estimate would result in a theoretical number of 928 breeders, genetically represented by our fry-collections. Considering a river continuum of $90 \mathrm{~km}$ in length and the estimated total grayling biomass of approximately $30 \mathrm{~kg} \cdot \mathrm{ha}^{-1}$ (Unfer et al., 2004), total grayling metapopulation in the Upper Drava should consist of around 4000 to 5000 potential breeders (Unfer et al., 2011). This indicates that our fry collection is estimated to roughly represent as much as $19 \%$ to $23 \%$ of the total number of individuals in the metapopulation. In addition, in a parallel study we investigated the comparability of fry versus adult sample-sets of wild grayling from a single sampling site within the Adige River, Northern Italy. We compared two adult samples with fry samples from two consecutive years. Both replicates of fry samples were genetically undistinguishable from each other as well as from adult samples, as indicated by similar standard genetic indices (i.e. number of alleles, heterozygosity) as well as non-significant outcomes of pairwise $F_{\mathrm{ST}}$ and AMOVA analyses (see Online Resource 2 for details).

Lastly, one could argue that fitness deficits arising from counter-selected allelic combinations could be important in juvenile grayling mortality in addition to stochastic factors. Under such a scenario, the allelic combinations of non-neutral markers of a random fry sample could be expected to be markedly different from that of an adult sample. However, while important when analysing molecular markers under selection, this should not lead to statistical bias 
when analysing neutral genetic markers, which in our case-study largely fit Hardy-Weinberg expectations.

Following these considerations, the here proposed fry-based sampling strategy seems to be a viable - but still rarely applied - option for $T$. thymallus, and probably also for other rheophilic fish species with similar life history patterns. Finally, since sampling of young of the year riverine fish is technically simple, rapid and cost-effective, sample collections can easily be established even within the framework of time- and resource-limited conservation programs or in the course of explorative studies, as the one described herein.

\section{> FISHERIES MANAGEMENT, CONSERVATION IMPLICATIONS AND FUTURE RESEARCH OBJECTIVES}

In contrast to all earlier studies, our molecular survey showed limited genetic introgression between stocking-introduced foreign and native grayling in the Upper Drava. This is definitely good news for conservation. The positive results of our genetic research have to be promptly communicated to the public, for example through popular-scientific articles published in local fisheries management and conservation magazines. This is not a trivial enterprise, since genetic research is generally complex and characterised by extensive professional jargon. Thus, a genuine trade-off in communication has to be found, where the complexity of genetic results has to be reduced to a minimum without losing scientific correctness (for strategies of research communication in fisheries science see Dedual et al., 2013). As stated above, stocking trends seem to have already changed in the area of interest. We highlighted a clear shift of stocking practices, from the introduction of trans-basin hatchery grayling towards a more conservation-oriented approach, within a framework where local grayling were used as brood-stocks. These are reasonable trends, positively corroborated by our recent genetic data. We have, however, not yet reached a conservation endpoint. For example, the adoption of genetic information for the selection of wild spawners in captive breeding is highly advisable. Specifically, it seems reasonable that the (few) Drava grayling specimens with signs of recent introgression were stemming from supportive or captive breeding, where admixed wild spawners had been used in the absence of genetic selection parameters. The combined application of nuclear genetic individual assignment tests - in conjunction with mitochondrial sequence information - will be a valuable tool for the selection of suitable spawners in future stocking campaigns.

Furthermore, the use of genetics in captive breeding is also useful to maintain genetic variability and to minimise inbreeding effects. We have shown through parentage analysis that our $T$. thymallus fry collection is the progeny of a relatively high number of spawners, resulting in weak patterns of family structure. This genetic insight also has to be considered when using wild spawners in supportive- and captive-breeding. Only an individual-rich, random mating-oriented fertilisation scheme, where the clutch of each female is partitioned and individually fecundated by a high number of randomly chosen males, will approximate life-history of $T$. thymallus and, hence, maintain genetic variability in the long term. In sharp contrast, current fish-farming practices generally depend on a small number of spawners and fertilise entire clutches with mixed-milt from two or three males only (Unfer, unpublished). Such an approach is likely to reduce genetic variability of hatchery strains and is probably even aggravated through sperm competition (Wedekind et al., 2007).

Follow-up genetic projects, extending grayling sampling to larger parts of the Drava system and its primary tributaries should be promoted in order to unravel microgeographic population structure and define numbers and spatial distribution of intra-basin management units for conservation.

Finally, we annotate that efficient salmonid conservation has not to be limited to strictly genetic endeavours. Innovative conservation strategies have to link current knowledge from science and management and team up geneticists, ecologists, fisheries managers, conservationists as well as policy-makers to sustainably manage unique, locally adapted salmonid populations (Piccolo, 2011). 


\section{ACKNOWLEDGEMENTS}

The present study was carried out within the framework of the project "ABaTe", funded by the Autonomous Province of Trento and the European Union (7th research framework programme Marie Curie Actions COFUND - TRENTINO PCOFUND-GA-2008-226070). The authors thank M. Mueller for sampling grayling of the Drava, B. Gum (University of TU München - Weihenstephan, Germany) as well as the 'Landesfischereiverband Bayern E.V.', S. Sušnik Bajek (University of Ljubljana) and J. Baer (Fischereiforschungsstelle Baden-Wuerttemberg, Langenargen) for providing grayling reference samples. In addition, we thank J. Wang for assistance in COLONY-based sibship reconstruction. Finally, we thank two anonymous referees for helpful comments and G. Flaim for constructive inputs and linguistic revision.

\section{REFERENCES}

Bardonnet A., Gaudin P. and Persat H., 1991. Microhabitats and diel downstream migration of young grayling (Thymallus thymallus L.). Freshwater Biol., 26, 365-376.

Belkhir K., Borsa P., Goudet J., Chikhi L. and Bonhomme F., 1999. GENETIX, logiciel sous Windows ${ }^{\text {TM }}$ pour la génétique des populations. Laboratoire Génome, Populations, Interactions CNRS UMR 5000, Université de Montpellier II, Montpellier, France.

Bruford M.W., Hanotte O., Brookfield Y. and Burke T., 1998. Multilocus and single locus DNA fingerprinting. In: Hoelzel A.R. (ed.), Molecular genetic analysis of populations: a practical approach, Oxford University Press, Oxford, New York, Tokyo, 287-336.

Clement M., Posada D. and Crandall K.A., 2000. TCS: a computer program to estimate gene genealogies. Mol. Ecol., 9, 1657-1659.

Dedual M., Sague Pla O., Arlinghaus R., Clarke A., Ferter K., Geertz Hansen P., Gerdeaux D., Hames F., Kennely S., Kleiven A.R., Meraner A. and Uebershaer B., 2012. Communication between scientists, recreational fishermen, and fishery managers: international case studies, context and lessons learned. Fisheries Manag. Ecol., 20, 234-246.

Diggs M.D. and Ardren W.R., 2008. Characterization of 12 highly variable tetranucleotide microsatellite loci for Arctic grayling (Thymallus arcticus) and cross amplification in other Thymallus species. Mol. Ecol. Resour., 8, 828-830.

Dudgeon D., Arthington A.H., Gessner M.O., Kawabata Z.-I., Knowler D.J., Lèvèque C., Naiman R.J., Prieur-Richard A.-H., Soto D., Stiassny M.L.J. and Sullivan C.A., 2006. Freshwater biodiversity: importance, threats, status and conservation challenges. Biol. Rev., 81, 163-182.

Duftner N., Koblmueller S., Weiss S., Medgyesy N. and Sturmbauer C., 2005. The impact of stocking on the genetic structure of European grayling (Thymallus thymallus, Salmonidae) in two alpine rivers. Hydobiologia, 542, 121-129.

Elliott J.M., 1994 Quantitative Ecology and the Brown Trout. Oxford Series in Ecology and Evolution, Oxford University Press, Oxford, $304 \mathrm{p}$.

Evanno G., Regnaut S. and Goudet J., 2005. Detecting the number of clusters of individuals using the software STRUCTURE: a simulation study. Mol. Ecol., 14, 2611-2620.

Excoffier L. and Lischer H.E.L., 2010. Arlequin suite ver. 3.5: a new series of programs to perform population genetics analyses under Linux and Windows. Mol. Ecol. Resour., 10, 564-567.

Fabricius E. and Gustafson K.-J., 1955. Observations on the spawning behaviour of the grayling Thymallus thymallus (L.). Rep. - Inst. Freshwater Res. Drottningholm, 36, 75-103.

Falush D., Stephens M. and Pritchard J.K., 2003. Inference of population structure using multilocus genotype data: linked loci and correlated allele frequencies. Genetics, 164, 1567-1587.

Fleming I.A. and Petersson E., 2001. The ability of hatchery-reared salmonids to breed and contribute to the natural productivity of wild populations. Nord. J. Freshwater. Res., 75, 71-98.

Fraser D., 2008. How well can captive breeding programs conserve biodiversity? A review of salmonids. Evol. Appl., 1, 535-586.

Freyhof J. and Brooks E., 2011. European Red list of Freshwater Fishes, Publications Office of the European Union, Luxembourg, $60 \mathrm{p}$. 
Gum B., Gross R., Rottmann O., Schroeder W. and Kuehn R., 2003. Microsatellite variation in Bavarian populations of European grayling (Thymallus thymallus): implications for conservation. Conserv. Genet., 4, 659-672.

Gum B., Gross R. and Kuehn R., 2005. Mitochondrial and nuclear DNA phylogeography of European grayling (Thymallus thymallus): evidence for secondary contact zones in central Europe. Mol. Ecol., 14, 1707-1725.

Guo S.W. and Thompson E.A., 1992. Performing the Exact Test of Hardy-Weinberg Proportion for Multiple Alleles. Biometrics, 48, 361-372.

Hansen M.M., Nielsen E.E. and Mensberg K.-L.D., 1997. The problem of sampling families rather than populations: relatedness among individuals in samples of juvenile brown trout Salmo trutta L. Mol. Ecol., 6, 469-474.

Herzig-Straschil B., 1991. Rare and endangered fishes of Austria. Verh. Internat. Verein. Limnol., 24, 2501-2504.

Jones O.R. and Wang J., 2010. COLONY: a program for parentage and sibship inference from multilocus genotype data. Mol. Ecol. Resour., 10, 551-555.

Jungwirth M., Moog O., Schmutz S. and Wiesbauer H., 1990. Raum- und Umweltverträglichkeitsprüfung der Kraftwerksprojekte Obere Drau 1, Teilgutachten 4: Ökologie des aquatischen Lebensraumes. Wien.

Kirchhofer A., Zaugg B. and Pedroli J.C., 1990. Rote Liste der Fische und Rundmaeuler der Schweiz. Documenta Faunistica Helvetiae, 9, 1-26.

Koskinen M.T. and Primmer C.R., 2001. High throughput analysis of 17 microsatellite loci in grayling (Thymallus spp. Salmonidae). Conserv. Genet., 2, 173-177.

Maitland P., 1995. The conservation of freshwater fish: past and present experience. Biol. Conserv., 72 , 259-270.

Meraner A. and Gandolfi A., 2012. Phylogeography of European grayling, Thymallus thymallus (Actinopterygii, Salmonidae), within the Northern Adriatic basin: evidence for native and exotic mitochondrial DNA lineages. Hydrobiologia, 693, 205-221.

Muhar S., Jungwirth M., Unfer G., Wiesner C., Poppe M., Schmutz S., Hohensinner S. and Habersack $\mathrm{H} .$, 2008. Restoring riverine landscapes at the Drau River: successes and deficits in the context of ecological integrity. In: Habersack H., Piegay H. and Rinaldi M. (eds.), Gravel-bed Rivers VI - From Process Understanding to River Restoration, Developments in Earth Surface Processes, Elsevier, 779-803.

Northcote T.G., 1995. Comparative biology and management of Arctic and European grayling (Salmonidae, Thymallus). Rev. Fish Biol. Fisher., 5, 141-194.

Olsen J.B., Bentzen P. and Seeb J.E., 1998. Characterization of seven microsatellite loci derived from pink salmon. Mol. Ecol., 7, 1083-1090.

Palstra F.P. and Ruzzante D.E., 2008. Genetic estimates of contemporary effective population size: what can they tell us about the importance of genetic stochasticity for wild population persistence? Mol. Ecol., 17, 3428-3447.

Persat H., 1996. Threatened populations and conservation of the European grayling, Thymallus thymalIus (I., 1758). In: Kirchhofer A. and Hefti D. (eds.), Conservation of Endangered Freshwater Fish in Europe, Birkhaeuser Verlag, Basel, 231-247.

Piccolo J.J., 2011. Challenges in the conservation, rehabilitation and recovery of native stream salmonid populations: beyond the 2010 Luarca symposium. Ecol. Freshw. Fish, 20, 346-351.

Pritchard J.K., Stephens M. and Donnelly P., 2000. Inference of population structure using multilocus genotype data. Genetics, 155, 945-959.

Schmutz S., 1995. Zonierung und Bestandsprognose von Bachforelle (Salmo trutta f. fario, L.), Regenbogenforelle (Oncorhynchus mykiss, Wal.) und Aesche (Thymallus thymallus, L.) anhand von Makrohabitatparametern in oesterreichischen Rhithralgewaessern. Doctoral dissertation, Univ. f. Bodenkultur, Vienna.

Scribner K.T., Gust J.R. and Fields R.L., 1996. Isolation and characterization of novel salmon microsatellite loci: cross-species amplification and population genetic applications. Can. J. Fish. Aquat. Sci., 53, 833-841.

Sell J. and Spirkovski Z., 2004. Mitochondrial DNA differentiation between two forms of trout Salmo letnica, endemic to the Balkan Lake Ohrid, reflects their reproductive isolation. Mol. Ecol., 13, 3633-3644. 
Slatkin M. and Excoffier L., 1996. Test for linkage disequilibrium in genotypic data using the expectationmaximization algorithm. Heredity, 76, 377-383.

Snoj A., Sušnik S., Pohar J. and Dovč P., 1999. The first microsatellite marker (BFRO004) for grayling, informative for its Adriatic population. Anim. Genet., 30, 74-75.

Spindler T., Zauner G., Mikschi E., Kummer H., Wais A. and Spolwind R., 1997. Gefährdung der heimischen fischfauna.. In: Spindler T. (ed.), Fischfauna in Oesterreich. UmweltbundesamtMonographien Band 87, Umweltbundesamt, Vienna, 54-75.

Storey J.D., 2002. A direct approach to false discovery rates. J. Roy. Stat. Soc. B, 64, 479-498.

Sušnik S., Snoj A. and Dovč P., 1999a. Microsatellites in grayling (Thymallus thymallus): comparison of two geographically remote populations from the Danubian and Adriatic river basin in Slovenia. Mol. Ecol., 8, 1756-1758.

Sušnik S., Snoj A. and Dovč P., 1999b. A new set of microsatellite markers for grayling: BFRO014, BFRO015, BFRO016, BFRO017 and BFRO018. Anim. Genet., 30, 478.

Sušnik S., Snoj A., Jesensek D. and Dovč P., 2000. Rapid communication: microsatellite DNA markers (BFRO010 and BFRO011) for grayling. J. Anim. Sci., 78, 488-489.

Sušnik S., Berrebi P., Dovč P., Hansen M.M. and Snoj A., 2004. Genetic introgression between wild and stocked salmonids and the prospects for using molecular markers in population rehabilitation: the case of the Adriatic grayling (Thymallus thymallus L. 1785). Heredity, 93, 273-282.

Uiblein F., Jagsch A., Honsig-Erlenburg W. and Weiss, S., 2001. Status, habitat use, and vulnerability of the European grayling in Austrian waters. J. Fish Biol., 59, 223-247.

Unfer G., Haslauer M., Wiesner C. and Jungwirth M., 2011. LIFE-Projekt Lebensader Obere Drau. Fischökologisches Monitoring, Wien. Studie im Auftrag des Amts der Kärntner Landesregierung.

Unfer G., Wiesner C. and Jungwirth M., 2004. Fischökologisches Monitoring im Rahmen des LIFE Projekts Auenverbund Obere Drau, Wien. Studie im Auftrag des Amtes der Kärntner Landesregierung.

Vähä J.-P. and Primmer C.R., 2006. Efficiency of model-based Bayesian methods for detecting hybrid individuals under different hybridization scenarios and with different numbers of loci. Mol. Ecol., 15, 63-72.

Van Oosterhout C., Hutchinson W.F., Wills D.P.M. and Shipley P., 2004. Micro-Checker: Software for identifying and correcting genotyping errors in microsatellite data. Mol. Ecol. Notes, 4, 535-538.

Wang J., 2004. Sibship reconstruction from genetic data with typing errors. Genetics 166, 1963-1979.

Wang J., 2012. Computationally efficient sibship and parentage assignment from multilocus marker data. Genetics 191, 183-194.

Wang J. and Santure A.W., 2009. Parentage and sibship inference from multilocus genotype data under polygamy. Genetics 181, 1579-1594.

Wedekind C., Rudolfsen G., Jacob A., Urbach D. and Mueller R., 2007. The genetic consequences of hatchery-induced sperm competition in a salmonid. Biol. Conserv., 137, 180-188.

Weiss S., Persat H., Eppe R., Schloetterer C. and Uiblein F., 2002. Complex patterns of colonization and refugia revealed for European grayling Thymallus thymallus, based on complete sequencing of the mitochondrial DNA control region. Mol. Ecol., 11, 1393-1407.

Weiss S., Kopun T., Sušnik Bajec S., 2013. Assessing natural and disturbed population structure in European grayling, Thymallus thymallus (Salmonidae): melding phylogeographic, population genetic, and jurisdictional perspectives for conservation planning. J. Fish Biol., 82 , 505-521.

Wiesbauer H., Bauer T., Jagsch A., Jungwirth M. and Uiblein F., 1991. Fischökologische Studie, Mittlere Salzach. Im Auftrag der Tauernkraftwerke AG, Vienna, 170 p.

Wolfram G. and Mikschi E., 2007. Rote Liste der Fische (Pisces) Oesterreichs. In: Zulka K. (ed.), Rote Liste gefaehrdeter Tiere Oesterreichs, Teil 2. Gruene Reihe des Lebensministerium Band 14/2. Boehlau-Verlag, Wien, Koeln, Weimar, 61-198. 